DRAFT VERSION JANUARY 15, 2020

Preprint typeset using $\mathrm{LAT}_{\mathrm{E}} \mathrm{X}$ style emulateapj v. 12/16/11

\title{
THE PHENOMENOLOGY OF TERRORISM: THE CONDITIONAL COUNTERVIOLENCE AS A RELATIONAL PHENOMENON
}

\author{
FAHimeh DehBaShi ${ }^{1}$ \\ ${ }^{1}$ Department of Philosophy, The University of Western Ontario, London, ON, Canada, N6A 3K7 \\ Draft version January 15, 2020
}

\begin{abstract}
Whether ends justify all violent means or only conditional violent means? The phenomenological analysis of terrorism prepares a way for looking accurately at how one can make sense of a major transition from an engagement to a disengagement of society. Phenomenologically speaking, Violent acts are interpreted based on intentional experience that conducts the social roots of violence towards an intersubjective relationship between oneself and the Other, understood as Ego and alter Ego. The connection between the $I$ and the Others emanates from two phenomenal concepts of love and hatred. On the one hand, These two concepts have bonded with the freedom of their subjects, so both the $I$ and the Others should be in permanent violence to keeping their freedom. On the other hand, the phenomenological concept of terrorism is examined through the justification of relational violent means, rather than an absolute violence. The main core of this paper is centralized on the formula of Trotsky who asserts 'ends justify means.' However, it must be differentiated between terrorists' actions that unconditionally use means and conditional violent actions, used by relational violent means. The latter wants to achieve some goals, such as restoring the self-respect and the personal identity of victims of terrorism, as well as decolonizing and protecting territories. Counterviolence, such as defending our national identity, is necessary to achieve these goals, but it should not be led to assassinating all humans, both civilians and statesmen. The contemporary violence can be thought of as a modern slavery such that it overlooks the idea that all humans are born free. Therefore, counterviolence is permissible without any extreme violence through different methods, such as protesting or making a real international court without any directorial and commanding aspects on behalf of colonialist leaders.
\end{abstract}

Keywords: The phenomenological concept of terrorism, intersubjective relationship, the $I$, the Other, absolute violence, relational violence, counterviolence, modern slavary, extreme violence, revolution

\section{INTRODUCTION}

In the modern world, terrorism is increasingly becoming an important concern in many countries, yet it is necessary to recognize terrorists' actions as objective phenomena. The phenomenology of terrorism requires a descriptive method to analyze terror and violence in the complex levels of sense in consciousness because terrorism "plays the role of a phenomenon, rather than a mere object in a philosophical perspective" (Dodd). In this paper, phenomenology is not used as a method, rather it is as a means of finding a way into philosophy.

The aim of this paper is to provide a framework based on phenomenological philosophy, examining the permissible domain of violence when it comes to both terrorism and counterterrorism. The key research question of this study is to address whether 'the ends justify conditional or unconditional violent means.' In doing so, the first and the second chapters are to review considerable amounts of literature to investigate two basic elements of terrorism including its historical alternation and its phenomenological approach. In the next part, I also examine the connection between the $I$ and the Others in violent acts. The fourth section presents the phenomenological concept of violence with two parts including counterviolence

fdehbash@uwo.ca or avoiding counterviolence, and the roots of terrorism. The final chapter draws upon the discussion of using relational phenomenology to violent actions in the spiral of violence and counterviolence between governments and nations.

\section{THE CONCEPT OF TERROR IN ITS HISTORICAL ALTERNATION}

The evolution of terrorism as an 'asymmetric threat' between the 1990s and 2000s revealed itself as political violence against civilians, as was seen in some parts of the world such as Northern Ireland and Spain. However, in 1998, a series of more intense attacks occurred in Kenya and Tanzania, with the bombing of U.S. embassies. Terrorism was a growing threat to the civilians and extended as asymmetric wars, such as a deliberate plane crash in the United States by Al-Qaeda on September 11, 2001, targeting those who were most vulnerable (Kurain 99). As a counterterrorism strategy, the United States and its allies used asymmetric warfare to overthrow the Taliban regime in Afghanistan which they were able to quickly achieve by defeating Al-Qaeda. In addition, a widespread insurgency in Iraq and Syria, called Islamic States of Iraq and Syria (ISIS), with the traditional hit-and-run tactics and terror revealed another asymmetric war against civilians of Iraq and Syria. The history of terrorism shows the targets of terror and horror are mostly conducted 
against civilians and oppressed nations.

In the scopes of a philosophical psychology, the historical perspective, and the political strategy, 'Terror' is an analysis of political events as a violent function; 'terror' is as an effect, and more importantly, when used as a political strategy, it is called 'terrorism' (Hodge 205). In the history of terrorism, the globalization (mondialatinization) of terror was important for some scholars, such as Kant, Derrida and Hanna Arendt. Derrida claims that through the globalization of terrorism, Christian, Roman, and Latin inheritance can be seen. In addition, Arendt asserts that, if the political events are privatized or depoliticized, the various dimensions of humans' conditions would be neglected; Kant, in his article (1784), defines the concept of history as 'future' to strengthen the universal history, such that if the time horizon of terrorism becomes cosmopolitan, the historical deviance would be reduced (213).

The transformation of the concept of political violence and its manifestations throughout different centuries have mutated the essence of terror. As Härter mentions, since the 16th century, the intentions and patterns of assassination have changed to a public, performative, and symbolic act of opponents who will risk their own lives by 'suicide attacks' or by bombing against a ruler to denounce unjust and despotic states (143). In the early modern period (the enlightenment's period), terrorists used violence publicly to express their motivations, such as an act of resistance against tyranny and despotism to stimulate the broad mass of population against a political or religious system with the goal of directing them towards a revolution to change the state (147). Political violence and crimes were conceptualized through legislation, legal discourse, and the alternation of courts by legal systems (148). The conceptualization of violence and terror has been extended to every dissident activity and has caused every political violence to be prosecuted.

In the procedure of conceptualization, states often consider the symbolic and public dimension of terror as the visible and public side of criminal activities (149). Thus, the plot of conspiracy becomes a crucial element in the conceptualization of political violence, so in early modern Europe, prosecution and punishment were legally practiced with different methods. By the end of the 18th and the beginning of the 19th centuries in Europe, notably in Germany and France, the specific nature of terror, crimes, and their legal conceptualizations as treason, conspiracy, and sedition against governments could alter the formation of courts, their procedures, and the new punishment regarding the symbolic and public purposes against unjust regime (150). During this time, media played a pivotal role in revealing the patterns of political crimes and legal responses through the images and "iconography of the terror, attempted against Henry IV with the anarchist action of terrorists" (163). The terrorists aroused public disputes and evoked the attention of the media to extend their demands and purposes. The authorities reacted in various stages to obliterate terrorists because of their violent deeds, as well as to deter plotters from their goals for the future (Ibid).

In contemporary history, with increasing Liberation Movements against governments, the definition of violence and terrorism has changed. As Staudigl asserts, violence is presupposed by social events, related to po- litical systems, as well as intentional actions of individuals which encroach upon the future or themselves upon others (51). If terrorism is defined as "the unlawful use or the threat of violence against persons or property to [attain] further political or social objectives," the national liberation movements, such as the African National Congress or Palestine Liberation Organization, are denounced (Bender 23). Moreover, all attacks and protests on American statesmen and diplomats, rather than its civilians, as well as those who tried to assassinate Adolf Hitler during WWII should be denounced. Furthermore, by the above definition of terrorism, the Afghans, the Cambodian resistant movements, and the military of Syria do not have the right to drive foreign invaders from their countries; hence the definition of terrorism is untenable. Furthermore, the seizure of innocent hostages is certainly an act of terrorism which brings horror and disgust to human beings.

The statesmen' views of terrorism and the attitude of the members of national liberation movements are different. For instance, in some views, all acts of violence, such as those against military targets, become terroristic acts, while the attacks against civilians in Afghanistan, Cambodia or Nicaragua should be tolerated to be free from communistic rules. Conversely, a national liberation organization trains guerillas to rescue citizens from colonists and to provide, for oppressed civilians, circumstances to decide independently for their territories. Individuals have the right to fight for their freedom, even though they revolt with violent acts against agents of the oppressive governments not against innocent citizens. Therefore, all political violence are not terrorism, but rather those tyrannical acts are terrorism by which innocent civilians are persecuted, proscribing them from their own rights to determine their destiny. In other words, colonialists assassinate humanness and terrorize the personality of civilians. As a matter of fact, the violent acts occur between 'oneself' and 'the Other' or 'Others, so it is necessary to be comprehended the connection between the essence of the ' $I$ ' and 'Others' to identify the nature of terrorism. The essence of the nexus is precisely perceived by the interpretive phenomenological analysis of violence and terrorism that contemporary phenomenologists have attempted to present.

\section{PHENOMENOLOGICAL APPROACH OF TERRORISM}

Terrorism as a non-phenomenological approach can be investigated through qualitative experiential problems such as "bureaucratic organizations, premeditated political motivations, and an organizational mission, rather than the actual nature of the terroristic threat or as a wartime policy" (Morris 220). However, the phenomenological perspective of terrorism is a practical understanding of society in the world which reveals how terrorism, in the physical world, is experienced in consciousness. Sharma asserts that "the givenness of violence to the consciousness of an individual should have non-specific and indeterminate characteristics of the violent experience" (224). Hence, the phenomenological perception of terrorism provides a bridge between philosophy and politics to comprehend its cruel nature (224). Here, we examine the epistemological basis of terrorism as a phenomenon 
to discern the language, the values, and the reasons behind violent acts of a group whose decisions are based on their interference in the political arena through violence. It is necessary to open a window towards phenomenology to understand the concept of terror, the practical methods of terrorists, and their purposes.

The phenomenological analysis of terrorism is a very effective form of analysis for qualitative data and the most proper method for looking accurately at how someone makes sense of a major transition from one situation to another in his or her life (Smith 3). The phenomenological interpretation of terrorism requires describing some phenomenological expressions which are necessary to comprehend the roots of terrorism and the fundamental motivations of terrorists. According to the philosophical foundations of phenomenology in account of Edmund Husserl's approach, the philosophical theory of consciousness and the description of specific forms of human consciousness are based on the theory of intentionality (Smith 1). Husserl claims that "intentionality expresses the fundamental property of consciousness [that] all phenomenological problems ... are classified according to it" (Ideas, 146, 357).

The definition of intentionality of consciousness is "the peculiarity of experiences (Erlebnissen) to be the consciousness of something" (204). Thus, "intentionality is often described as the 'directness' of consciousness and intentional experiences which have the peculiarity of relating in various ways to present objects...; an object is 'aimed at' ['abgezielt'] or directed towards something in a relevant sense" (Smith 2, qtd. Husserl, Logical Investigation 11, 558). Husserl's concern is to provide the theory of intentionality in the framework of all phenomena, including sensations and phenomena in the sphere of consciousness.

Husserl emphasizes on the connection between 'intentionality,' 'act,' and 'experience,' but any nonintentional phenomenon is not to be called an act. What this means is that an act is an intentional event of consciousness that the subject can discern by reflecting on his/her experience. Hence, an act is the experiential component of an intentional event, so the paradigm of intentionality in the usage of perceptual notions is called the act of perception (Smith 3). For Husserl, the objects of acts are various types of entities either "concrete or abstract, particular or universal, simple or complex, and immanent' mental entities or events which occur as a part of the stream of consciousness" which enable us to attain the intentional experience of them (6). Consequently, in the phenomenological study, a lived experience emerges from "instantiations of experience," trying to make sense of these experience (Barrelle 131). Accordingly, the way of understanding the acts of violence and the terroristic events should be oriented towards the intentional consciousness on these acts, as phenomena, to make sense them in a lived experience.

Violence is a phenomenon that extends beyond its physical and visible forms of appearance. It is considered as an intrinsically meaningful event which involves the fatal attacks to identify a terroristic identity with its "existential vulnerability" of a person or even of his own social identity (Staudigl 50-1). Thus, the experience of violence should be beyond understanding because it relies on an act, an victim, an offender, a motivation, a political background, and even a historical impact. The phenomenon of violence involves the vulnerable effects on others that go back to the intracorporeal structure of existence. The phenomenological investigation analyses the roots of violence and the constitutive part of the inter-subjective relationship between oneself and the Other. Terroristic acts affect the identity of oneself who disengages from his society.

\subsection{A Major Transition of Individuals During their Disengagement from Society}

The structure of violence in the phenomenological approach is based upon the "immanent accomplishments of oneself and [his engagement with the world and his society which illustrates the relation between oneself and the Other] to shape his understanding of the relation and self-conception." (Staudigl 44). The phenomenological essence of disengagement from the society creates the violent extremism due to various reasons including ineffectiveness, burnout, and marginalization. However, for protecting personal identity, the engagement or disengagement of a person with his/her society is because of social reasons but not political or ideological issues.

On the one hand, the domain of the engagement with the society is in consistency, protecting personal identity, and acting on ethical and cultural norms. On the other hand, all these categories direct towards a conflict if they are carried out with extremist behaviors because of the disengagement from the society. The phenomenological process of the engagement and the disengagement with the society includes three phases in "the life-cycle of radicalization- 'Becoming,' 'Being,' and 'leaving" to shape and reshape the personal identity" (Barrelle 130). The members of extremist groups are in the 'becoming' process, while they emerge their new personal self to be identified with the 'being' process. Finally, they find something else to manifest their abnormal behaviors in and have a complete break from social norms. These three processes reshape the identity of extremists to move away from marginal and separatist groups, and to find a place in the society and to speak for matters that they perceive as important (133).

The personal damages of extremist group members include "anxiety, paranoia, poor physical health, drug/alcohol abuse, ... loss of relationships with family and friends, disrupted education and career, criminal charges and imprisonment" (Horgan 30). If the members become disillusioned with their group members, extremist leaders and their radical ideas, they disengage from violent extremism and revert to social engagement. They emerge "their own personal identity, find own ideas, and move to the "proactive self-development"' (Barrelle 134). The new circumstances of these people, who have moved from the paradox of the disengagement and the engagement between extremism and mainstream society, provide to them a stable sense and ultimate identity. In addition, the reconverted people achieve a coherent set of ideas and beliefs which enable them to live with others in a peaceful coexistence (135-7). Therefore, their identities intertwine with others rather than the group members of radicalism. In the next section, I examine the relationship between the $I$ and the Others which is viewed from the perspective of love 
and hatred. The connection between the $I$ and the Others shows the reason of people's engagement and their disengagement of societty.

\section{THE CONNECTION BETWEEN THE $I$ AND THE OTHERS IN EXISTENTIAL VIOLENT ACTS}

The scrutiny of terroristic and violent acts as social phenomena, to determine the causes of terrorism, demands an intentional representation of the relationship between the $I$ and the Others as the Ego and the alter Ego. The connection between the $I$ and the Others is based on the empathy that is ascribed to the intentional act of me on the Others and vice versa. This connection is based on a social community rather than solipsistic individuals. According to Husserl, "The communarization (Vergemeinschaftung) enables the second Ego (the Others) to be appeared in the primordial Ego to be similar to the $I$, who discerns [his/her] community with his/her lived experience" (Husserl, Ideas 124). Hence, not only the $I$ can represent the Others, but also the act of the $I$ is occurred by the given sensible effect of the same Ego. According to communarization, the Others reveal a natural part of the $I$ in the original form of their living, so the Others' external presence is a live organism similar to the $I$ (Ibid). As Ferrarello mentions, the lived experiences of the Ego and the alter Ego are mirrored images of each other with consistent intersubjective structures. The consistency between the Ego's act and the Other's act helps they live together (202). The $I$ lives in a world which constitutes his own identity, the horizon of others, and a homogeneous community between all humans.

The relationship between the Ego and the alter Ego gives "a universality of one's own life and the life of community" which performs a synthetic unity to create the love between the $I$ and the Others (179). This relationship constitutes the Others as the $I$ to determine a transcendental social life in which the ethical being intertwines with the social being and the intersubjectivity of life-world is revealed for all (194). As Merleau Ponty indicates, when the $I$ commits an act, it is not only in his own name, but also it is occurred by the Others which makes a connection. What we do to others is respected as noble souls (Humanism and Terror 109). Merleau Ponty's approach of the connection between the $I$ and the Others is that the Others are as auxiliary egos to carry out themselves in the $I$, but the Others, who know "the place of truth, are not in the struggle [against each other rather] they are in the 'co-presence' to prevent from narcissism and create a perpetual life" (Institution and Passivity 118).

The connection between the $I$ and the Others emanates from two phenomenal concepts of love and hatred. The alienation of the $I$ from the Others and the recreation of the $I$ by the Others are both grounded to find a solution for violence by "the resumption of the For-Others in the For-Itself, [as well as] the creation by the For-Itself of a For-Others [which is] justifiable in the eyes of the Others, so self-positing-doing is the only solution" (119). The alienation and the reconciliation of the $I$ and the Others reveal that the duty of the Others intertwines at the same time with its right; it means that the respect for the freedom of the Others involves non-intervention of the Others in me and the attention to their own responsibility. Here, self-positing-doing indicates that I substitute another for myself, and others substitute me for themselves; thus, "I am others and they are also me which makes an immediate unity of the Forself and the For-Others" (120). The process of connection between the $I$ and the Others must not be sometimes dominated by the $I$ or sometimes by the Others to be considered as Communist Party, but this connection involves sympathy, rather than adherence (121). In the phenomenological approach, the connection with the Others or being nearness to the Others, as Heidegger indicates, is understood existentially but not categorically.

From the existentialists' standpoint, the being of the $I$ and the Others does not have the ontological character, but rather "this being-there-too 'with' them is oriented in Dasein; the 'with' is the existential character of Dasein which means the sameness of being (Sein). The world of Dasein, also, is a with-world (Mitwelt), ... and Being-in is Being-with others (Mithsein) (Heidegger, Being and Time 115). Thus, the 'Dasein-with' of others is disclosed only within the world because Dasein, in-itself, is essentially being-with (Ibid). In Heideggerian sense, violence is the essential destruction of being (wesen). Being of a thing is not its entity, but it is its Dasein; in other words, the being (wesen) of things is "their nearness together that can be decimated by a technological proximity and speed" (Rockmore 274). The things' true nearness is ceased by entering the technological world, and they go towards indifference or violence, led to get away from and disgust to each other.

Two aspects of love and hatred within the connection of the $I$ with the Others have bonded with their freedom. John Paul Sartre makes it clear that the Others is given to us not as an object but as another freedom who challenges with the $I$ to attain the possibilities of becoming free. The $I$ looks at the Others and reveals their being and makes them what they are in-themselves; also, the Others look at me and reveals my being, and their look to me makes me what I am in-itself (Santoni 12). Sartre's interpretation of the connection between the $I$ and the Others involves a structure of Hegelian analysis of the Master-Slave relationship although it represents an important difference. Sartre points out that the Master-Slave relationship is not reciprocal, whereas the challenge between the $I$ and the Others is to recognize their self-consciousness to have an "authentic intersubjective" relation between themselves $(17,19)$. As Sartre explains, violence is posited by the $I$ to destroy the Others' freedom as an object, so the violence with the Others is a dead relation since "no reciprocal humanized relation can emerge, [but rather violence is to destroy] the co-existence and to dehumanize" (Fleming 30).

Sartre explores the objectivity of violence in capitalism, embodied in the relationship between an employer as the $I$ and his worker as the Other, that $I$ violates his/her right by confining his "freedom and subsuming him to the reproduction of capital at an expanded scale" (31). However, the deconstruction of this relation between the worker and his employer leads to denying the range of possibilities that the worker has. Here, the existential violence is not an oppression from the employer, but rather the oppression is that a worker restrains another worker to conform his own identity with his rank given to him not to struggle against his rank (32). This 
kind of oppression which determines the Others' identity as workers is parallel to "fraternity-terror" (33, qtd. Sartre Critique 7360). 'Fraternity-terror' derives from the free praxis of the $I$ that may destroy the freedom of the Others who have "the possibility of becoming Others" as their own identity, rather than the forced identity by the $I$ or putting the Others in parentheses of demands of the $I$ (Ibid). Therefore, representing a worker, using his/her working class by the employer, makes impossible to establish an authentic relationship between the oppressor and the oppressed (the $I$ and the Others).

It seems that the phenomenological analysis of Sartre on the connection between the $I$ and the Others focuses on the social and historical approach, despite his emphasis on ethics. His analysis stresses on terrorizing the personal identity and humanness of the Others which is consistent with violence rather than terrorizing them physically. For Sartre, the moral violence would be justifiable if it is in a way of concrete struggle of the workers against "their bourgeois oppressors ... which is a counterviolence against [violent acts]" (Santoni 117). In other words, the counterviolence of the Others against the $I$ is morally permissible if the Others attain the possibility of carrying out their own identity by their freedom. Hence, fraternity, emanated as love, can stem from hatred to become the most immediate form of terror, so "the fraternity, in opposition to group, [engages in] violence to bear the name of terror" (44). Consequently, both the $I$ and the Others should be in permanent violence to keep their freedom from alienation.

\subsection{Power as the Will of the I against the Resistance of the Others}

The Hegelian perspective of Sartre on violence between the $I$ and the Others, as Hanna Arendt indicates, shows that violence is no longer a "marginal phenomenon, but it is a contingent necessity, [as such I can destroy] humanity in him and realize in myself his inhumanity" (Arendt, On Violence 90). In other words, the $I$ suppresses the Others' freedom by my power as an alien force. Violence appears because the I's power is endangered by the Others, but it is finished when the power disappears. Thus, the opposite of violence is not nonviolence, but it is the annihilation of power (56). If human beings are forced to act without freedom, they conduct violence toward others, so violence is "a pre-political act to liberate humans from the necessity of life for freedom of the world called felicity (edaimonia) in the philosophy of Greek" (?). Power is a limitation of the Others' existence because the $I$ can possess a monopoly by acquiring the means of violence although violence can also destroy power by the Others (201-2). For Arendt, if we compare all organic beings, they show their distinctions. However, the otherness is only found in the "multiplication of inorganic objects that can communicate himself with the $I$ not as something thirst or hunger, but the $I$ can share with alive everything and becomes uniqueness although the humans' plurality is a paradoxical plurality of unique beings" (176).

The relational identification of the $I$ and the Others is not an abstract representation of self by self, but it is a concrete relationship which should alter by their in- habitations in the world. Emmanuel Levinas is an existentialist and phenomenologist who justifies the concrete relationship of the $I$ and the Others based on sojourning in the world. He, in Totality and Infinity, claims that "dwelling and being at home is not as a container but it is as a site, a position, and an intention where the $I$ can because it maintains the body as itself" (37). In addition, the Other is not simply in another locality, but it is "the alterity of the $I$ that its inhabitation in the world is only formal;" hence, the $I$ sojourns in the Other which is under the power of the $I$ without divesting of its alterity (38).

Levinas, in contrast to Sartre, produces a peaceful relation between the $I$ and the Other because he believes that the same identity between the ego and the alter-ego creates peaceful coexistence (67). This coexistence is not the same as what Heidegger calls coexistence with "being in general, on comprehension, and on ontology [which is the being of] 'We' prior to the $I$ and the Other." For Levinas, being for the Other is not a relation between concepts whose comprehension would be coincide (261). The objective relation of the $I$ and the Other is not the negation of the $I$ by unifying them. Conversely, it is "a face to face position which illustrates the universality with all possible collections of terms are founded... to posit being as desire and goodness," rather than the modality of coexistence that Heidegger asserts (304-5). In other words, the being of the $I$ is to produce desire and goodness to prevent from isolating itself and then to tend towards the Other, but the $I$ is understood with the same position it already had with the exterior gesture.

As Levinas mentions, the conflict between the $I$ and the Other is in where the Other reduces to the $I$ concretely, and the $I$ understands war in the tyrannical oppression which is experienced from the totality of the state. Levinas asserts that the relation between the $I$ and the Other is based on interlocutor and goodness rather than violence and terror (47). In his phenomenology, murder is committed to annihilate, rather than to dominate, which renounces a being independent from itself, but the Other is the face who can express himself in the $I$ (221). If the $I$ threatens the Other, it would be by nothingness in his being, as well as by a will in his action which is exposed to a foreign will. For example, an enemy or God over whom the $I$ cannot have power and they do not permit me to use my volition which is led to my egoism, but this volition goes towards desire that does not coincide with the need of the $I$, but this desire directs towards the Other (236). The I's volition and his desire for the Other liberate the $I$ from the egoism. In other words, the $I$ devotes himself/herself for the Other. Hence, murder is revealed in the cruel world with the criterion of humans' relations (Ibid). The $I$ cannot isolate from society even with the Other, so the $I$ connects to an existence beyond all ontology because he has an ultimate relation with Being.

To sum up, For Levinas, the interaction between the $I$ and the Other bears a force and weight represented by the ethical relation in a type of calling (summons) the Other to be an interlocuter rather than to terrorize and to do violent acts against him (Keen 446). Levinas asserts that the nature of being interlocutor illustrates that the $I$ connects face-to-face with only the Other, rather than the Others. Derrida claims that Levinas' approach 
is not mere moral, but it demonstrates the essence of ethics or ethics of ethics. In other words, there is "a phenomenological feeling of being responded ethically; Hence, murder and terror are in the horizon of being where the $I$ resides to negate the Other when the $I$ confronts to the face of the Other" (449). However, if the I hears the voice of the Other it is impossible to terrorize the Other because the $I$ possesses the being of the Other, so if the $I$ probably terrorize himself or herself, he or she does a violent act and harms to the Other (Ibid). Consequently, Levinas considers murder as a total negation to reject the Other in the context of totality and infinity with the phenomenological relationship of the $I$ and the Other.

A framework of 'phantasm' to the $I$ and its connection to the Other is presented by Derrida. He focuses on the image of the $I$ which "weaves the universal and the individual together in [itself]," so the Other would already come in the $I$ as phantasm (Derrida, A Taste for the Secret, 89). He believes that the phantasmal relation of human beings is regarded as a "pre-originary intervention of the Other in me" (Ibid). In the other sense, we can encounter the Other only through "foundational characteristics of subjectivity" (Tahmasebi 83). For Derrida, the image can neither be created nor destroyed, but the image of the Other in me can extend towards terrorist acts. However, the law prohibits the phantasm of terrorizing that tends to do terroristic acts (Mitchell 290). Thus, terrorism, as such Derrida claims, cannot be historically eliminated, but it comes back, appears again as a concept with its symbol, and its phantasm is revealed in everyday life of humans.

\section{THE PHENOMENOLOGICAL CONCEPT OF VIOLENCE}

Violence is a social event in a system which is founded with an agent or as intentionality, but in the phenomenological approach, pleasant or violent events are actions or deeds of individuals with their intentional experiences (Birchall 283). Heideggerian approach interprets 'terror' (Erschrechen), rather than 'violence,' in the ontological perspective to be propounded as a metaphysical issue. Heidegger defines terrorism as a "fundamental mood of our time of 'technological enframing' (Geste ll)" which is a state of humans' existence not as a means to an end (Mitchell 181). Enframing represents an extreme danger for humans by technology to forget their own essence, so the nature of terrorist's threat we face today, in Heidegger's idea, involves the ontological notion with its continual presence. The enframing of technology considers humans as by-products and the alienation of their beings in-themselves (Scrivner n.p). In other words, 'being,' in the contemporary time, dominated by technology, is terrorized. Hence, terrorism is not mere activities of terrorist groups, but rather terrorists challenge with the 'ontic' (being) (Mitchell 182).

In the modern world, terror is not the same as war because in the warfare, the oppositional structure of friends and enemies affirms political theories and military practice. The political decisions on war are not fully made by leaders who would be in the control of main determinants of political matters, but politics directs towards a plan to consider humans' general security (190). The logic of politics is the logic of replacement for both war and peace. However, terrorism is a war in the mirror of technological consuming beings rather than against the state of peace (192). Thus, terrorism is not only a conflict against soldiers or civilians, but also it can use everything as its target, so its essence is available and applicable to transform beings towards its targets in the technological world.

As Mitchell indicates, terror is experienced, in Heideggerian attitude, at both the abandonment and the participation of being; in some sense, terror puts 'being' into entities to preserve 'being' from withdrawing and forgetting because "terror insists upon a moment of concealment of [beings in the] technological circulation" (199). Understanding terror as withdrawing being is not a simple presence and absence of being, but it is between these two which establishes the world of non-presence and non-absence. Therefore, the annihilation of being is impossible, but when withdrawn, the world becomes denatured, and the security of being is endangered, in which case Dasein should guard the truth of being in the experience of terror(213).

\subsection{The Facile Formula of 'Ends Justify Means of Violence'}

Leon Trotsky (1879-1940) rejects the formula of 'ends justify means.' Trotsky argues that the dialectical interaction between ends and means should be conditioned because ends are not pre-given affairs to select means without considering means' impacts on the ends. As an illustration, it is impossible that the mass is replaced by terrorists to change the old state, but rather the mass' movement with their "expedient expression" can revolt to change the state (Birchall 254). Sartre believes that "ends justify means, but the means which define the ends" (Ibid). Although he claims that his idea is very close to Trotsky's idea, it does not seem that they have the same views.

Sartre confronted with the questions of violence and terrorism when the Germans Occupied France. The French Communist Party (PCF) provoked its members to repress Nazis and encouraged them to engage against the occupying forces by indiscriminate acts. The PCF's slogan was 'Chacun son Boche' (Let everybody kills a German) which invites to kill German soldiers. However, the German authorities responded them by denouncing that the resistance of fighters must not be considered as terrorists and criminals; hence, The German forces transferred PCF to the prisoners of war, as the United States behaves with its prisoners in Guantanamo Bay almost 60 years later (255-6). Sartre did not criticize PCF's strategy, and he declares that "the violence of the national liberation struggle is a response to the existing violence of colonialism" (257). Over the history of terrorism and wars, such as 11 September in the 2001s, the Nuclear bombing of Hiroshima or North Vietnam in the 1960s, civilians were the main victims (259). 'Innocent civilians' are a major part in 'terrorism,' so far as the moral and political arguments constantly prove terrorists' actions are indefensible. Nevertheless, modern terrorism is deeply rooted in the gross inequalities of wealth and positions.

Hanna Arendt asserts that terror in a totalitarian government is a means for the suppression of opponents. 
The chief aim of terror is to liberate the forces of nature or history by humans' actions, so "guilt and innocence become senseless notions, and the guilty stands in the natural and historical process which judge over inferior races, over individuals [who are] unfit to live, over dying classes and decadent people" (The Origin of Totalitarian 464-5). Terrorist do not apply laws, but execute the law of movement of natural or historical forces in accordance with inherent laws (Ibid). Historical forces concern in the totalitarian political ideology, such as Talibanist, described as an enemy because its target is tyranny and murder.

Explicitly, the natural force has the enlightened goal of liberty and democracy in life, which has become the dream of innocent nations of Iraq and Afghanistan (Fry 47). Total terror, by struggling humans against each other, destroy the space between themselves to enhance their movement (Arendt, The Origin of Totalitarian 466). However, some violence possess successful techniques to social control, such as students' movement that occupies office buildings or Black's powerful movement which rebels in their campuses (Arendt, On Violence 18).

On the one hand, for Arendt, violence is unpredictable and dangerous with the indiscriminate characteristic and without any guarantees for the proper outcome. Arendt describes violence as an instrumental activity to achieve certain ends although "it becomes self-defeating when it overwhelms any initial end" (Fry 45). On the other hand, violence can be justified as a means to combat against the negative end of history and construct the proper one (47). Indeed, performing action as a means to an end reveals the unique personal identity, while the physical identity may be appeared without any activity (Arendt, The Human Condition 179). Thus, similar ends attain easily because they can depict humans' capacity to act and speak simultaneously to eliminate the power that leads to a violent act. Some violence, as structural violence, use the means of murder to achieve its end, whereas other violent actions play an ideological function as subjective violence which are worse than structural violence and their targets are unarticulated (Fleming 21). "The structural violence is identified as a fundamental part of modernity and social relationship of capitalism," such as the violence, defined in terms of some laws which violate humanness and justice by colonists (24). Sartre, in his notes of 1964, differentiates between violence and terrorism. For him, Violence as political weapon is necessary when mass can be free from the shackles of structural violence, while violence as a political assassination is not permissible (27). Therefore, the violence as an act of counterviolence is permitted to achieve nations' freedom if it is not conducted with terrorizing and murdering.

\subsection{Counterviolence or Avoiding Counterviolence}

There are some possibilities to avoid counterviolence, such as negotiation, withdrawing forces, allowing independence, and stop torture, which need taking ethical responsibility to improve circumstances. However, the true face of colonialists shows that their actions need counterviolent acts because of their oppressions against mass; thus, the acceptability or non-acceptability of counterviolence depends on the method of its application in soci- ety. For instance, some violence negatively destructs the world to keep human beings in the state of sub-humanity (29, qtd. in Sartre notebooks 405). Conversely, other types of violence stream from the motivations of anticolonization to achieve the freedom of exploited nations and to protect their personal identities; thus, this violence has the essence of counterviolence against the system of violence to construct the real world of mass and humanness.

Santoni mentions, Sartre's argument is to avoid counterviolence even as a solution for a problem, and it should not be employed to conceal a mistake. He claims that exploited nations, especially libertarian movements should play "the self-limit role in the means-ends synthetic unity ... to rigorously limit the use of [violence] and acknowledge it as inhuman to those who undergo it" (149). Here, the conceptual separation of terrorism and violence identifies that terrorism, in contrast to some violence, needs to be denounced through the counterviolent acts, which their own essence would not be violent if they are performed conditionally. In spite of conceptualizing terrorism and violence with the criterion of 'counterviolence,' the modern terrorism conceals its essence.

According to Arendt, a fundamental difference between modern terrorists, as dictatorships, and all other violence in the past is that terror, today, is not used "to exterminate and frighten opponents, [but it is] an instrument to govern terrorists on mass who are perfectly obedient (The Origin of Totalitarianism 6). In other words, terrorists, today, accomplish their acts without any "preliminary provocation," and they know that victims are innocent, whereas in the Bolshevik German system, Nazis never admitted that their practice is against innocent people (Ibid). Furthermore, the economic interests of a small group deliberately sacrifice a great part of national wealth to expand the instruments of violence. Statesmen try to increase their power by violent device, such as their police and their army, while they left the greater gains which sustain the economic body of countries (136). Another contemporary violence involves the modern slavery such that it overlooks the idea that all humans are born free, but powerful politicians deprive people of their freedom (297).

Fanon, in contrast to Arendt, defends of acting violence with a revolutionary message to attain liberation. Fanon considers the absolute violence as means to gain the end, but he declares that the spiral means of violence and counterviolence between statesmen and nations to achieve liberation would be endangered by colonialists (Sonnleitner 287, 9). For him, certain ends justify absolute means even terrorism. Fanon proposes three goals for his declaration with three arguments. These goals including promoting individual self-respect, realizing political independence, and creating a new humanity (289).

Accordingly, Fanon's argument for the first goal is against colonialism which denies individual self-respect to secure the political and economic dominance and considering oppressed people with an inferior culture and the negation of values (Fanon, Black Skin, White Masks 30). As long as "dreams of liberty [are impossible to occur, the theory of] absolute evil of natives or settlers is made" (Fanon, The Wretched of the Earth 93). The compelling evidence is in the Algerian War of Independence (19541962 ) that nonwhite natives of Algeria were encouraged 
to adopt white French culture, yet they did not accept to have the same culture with whites. Thus, "the colonialists create a dichotomous line of settlers and native to make the native dehumanized individuals" (Sonnleitner 290). Obviously, violent actions become justified if they can be done by "nonviolent activities" through protests, the stoppage of work in a few industries, or boycotting buses. (Fanon, The Wretched of the Earth 66). For Sonnleitner, natives have to develop their self-respect by "controlling their lands and providing their sustenance, so both nonviolent and violent actions are capable to redistributing lands and bring both dignity and sustenance" (291). Nonetheless, Fanon claims that the only violent actions have capacity to protect lands and to provide sustenance for natives, so violence and terrorism are quite persuasive means to achieve targets (Ibid).

For Fanon, the second argument of terrorism is political independence, destructed by colonialists "in a capitalistic society which are accidentally white" (Black Skin, White Mask 202). Violent actions cause the capitalist colonial exploitation to appear (Fanon, The Wretched of the Earth 66). For example, the settlers of Algeria consider the native people as animals in their communications and behave with them violently. Hence, nonviolent actions cannot make the native independence, but they can attain their independence through violent actions (43). Fanon justifies creating a new humanity as a third argument by "decolonization [which attains] by a murderous and decisive struggle between two protagonists" (36-7). By comparing between natives and settlers with slaves and masters, Fanon confirms that oppressed people must bind together to recognize their consciousness of their national identity and destiny (92). Also, national culture will attain by fighting for liberating nations to recreate their personal identity and keep themselves in existence (233).

As Fanon indicates, the world should represent "the value of a non-exploitative new humanity, rehabilitate mankind, and make man victorious everywhere once for all" (106). Fanon's justification to his declaration is acceptable if one agrees with the formula of 'ends justify absolute means.' He offers the dualistic point of view about settlers and natives as oppressor and oppressed people, but he is forced choose between violence and inaction as nonviolence. Nevertheless, he prefers to choose violent actions to attain the ends of self-respect, realizing political independence, and making a new humanity. Ultimately, for Fanon, the upward spiral of violence and counterviolence between oppressors and oppressed people makes the requirement of terrorism and all revolutionary violence.

The complexity of politics and ethics in contemporary forms of violence creates the problem of recognizing anticolonial struggles and terrorism led to the assassination of innocent civilians (Crooks 84). The violent actions would be equal to the complete destruction of ethics, such as the suffering of Iraqi and Syrian civilians as the Others, by the U.S.A and ISIS. In detail, many civilians are killed by the explosion of the bombs and their bodies violently are dismembered or scattered (Puglies 221). However, victims concern of the Others' death, rather than their own death which depicts the dimensions of ethics towards the otherness.

Claudia Card contends that the legitimacy of coun- terterrorism is simply justifiable if its original attack is not conducted towards an act of war because the "armed forces [inflict] intolerable harm, such as the attack of United States' armed forces against Afghanistan led to the death of many civilians and children" (Questions Regarding a War on Terrorism 164). Hence, the counterterrorism is complicated since we would not determine its essence, so individuals should act according to their ends rather than means (Kant 80). On the one hand, terrorism is not an identity, as British or Iraqi, and all terrorists have not common goals belong to a unified organization or the same opponents. However, the victims of terrorists are the same including women, children, and all innocent civilians. On the other hand, the method of self-defense is morally permitted in certain cases as an answer to a charge of violent crime but without using the extreme means.

\subsection{The Roots of Terrorism and Extremism}

The absence of political and personal freedom makes people frustrate in many situations. They intend to carry out their dreams of freedom and independence, but they are not bloodthirsty murderers (Bender 47). Nevertheless, they make mistake when they use means to acquire their targets. They replace nonviolent means by violent ones, such as the attack of hijacking, kidnappings, or suicide bombings. When "social exclusions of refuges, immigrants, or the poor become naturalized through legal constitutions, the central extremism is created; moreover, if the egalitarian of welfare systems fades and the right of violence against immigrants become legitimized, terrorist actions are emerged" (Crooks 87). The minorities are neglected and marginalized because they do not have extra profit and surplus values, and their culture is not dominated, annihilating gradually. We understand the conditions of minorities who intend to retaliate against their present circumstances, so they become stateless terrorists because they lack the national sovereignty.

As an illustration, the interview of Sa'at Mokhtan with an ISIS commander (Abu Yusuf), in 2017, reveals that ISIS' purpose is to wreck Western governments in where they have lived. He explains that Western governments talk about the importance of human rights and the freedom of religions, but their Muslim inhabitants are disdained and marginalized citizens. "I wanted to stay in the same society that I grew up," he said, "but my feeling told me: You are just a Muslim, a Moroccan, never accepted" (Tasnimnews, Iranian Newspaper). Moreover, "the invasion of the U.S.A against Iraq in 2003, [which weapons of mass destruction were not used], but Iraqis were tortured in the Abu Ghraib prison..., so every [government] has the chance to free its citizens, if not so, it is its own problem" (Ibid). It is right that the world is not fair, and many religious people in different countries are considered as the minority. However, the war of ISIS that they have set up is not jihad; the jihad is that they had to stay in Europe and pursued their requests by negotiating or protesting against injustice and the shortage of laws.

In the contemporary violence, the national sovereignty is replaced by the state's sovereignty because the citizenship's right has been fading, but the contemporary post-fascism permits us to reject the political fight that 
Fanon declares in his analysis of colonialism (Crooks 88). For Fanon, the core of anti-colonial struggle is to annihilate colonialists because they provide the violence of face to face between natives and the Others and destruct humans with the feeling of hate towards the Others. Fanon suggests revolutionary violence which makes man fearless to restore natives' self-respect and recreate a new man (Fanon, The Wretched 55). Crooks claims that the new man is someone with the elevated consciousness of human rights which fosters the anti-egotistical concept of power but not the national power (Crooks 92).

Some scholars contend that violence and power are not the basis of realistic politics even in the most cases of selfdefense which emerge from the fear of the Other. Gandhi and Levinas are those who restrict the use of violence because they believe that "violence is not automatically justified even in defending against the Other" (Tahmasebi 144). The ethical aspect of liberation, in their views, is visible which provides the ethical resistance of terrorists. For Levinas, murder morally is not the practice of power over another power, but the murder attempts to remove whatever exceeds the I's power (124).

Terrorism is a high degree of mutuality for the attack against each other. To clarify, the bombing attack against the Twin Towers in the United States, September 11, is the distant effect of providing weapons to train individuals in Afghanistan for becoming enemies of the Soviet Union, who have now become the enemies of the United States (West 226). Derrida suggests the term of 'autoimmunity,' which means "the immune system of an organism responds against its own tissues, cells, or cell components, [to reveal the reasons of the event of September 11, including] the Cold War, the worse than the Cold War, and the vicious circle of repression" (227). Through the contemporary terrorism, the political reality is reduced to a combat between Western democracy and bin Ladenism. The state's deconstruction by autonomous forces becomes legal in "international pressure groups and politics, which is not the same as workers' struggles, stop-work meetings..., office and factory occupations" (232). Nevertheless, the autoimmunity of the autonomous forces is led to monopolize violence and their sovereignty to repress civilians or weak governments, who do not possess the powerful technology to combat against terrorists.

According to Michell, the historical facts of terrorism reveal that colonialist states, who are the master of technology, cause past or present terrorists to be future leaders, so terror can be an instrument that states can use to achieve their ends. The evil of terrorists is referred to their means which they use but they are unsupported by moral principles (278). Derrida's approach of terrorism is focused on its "psycho-political structure" which begins with exploiting civilians (279). In the modern world, the cold war is replaced by terrorism. Terrorism can be compared to a virus or cancer with invisible cells which are hidden inside the body, waiting to strike. The immune system of body is destructed by the antibodies and antigens on the biopolitical conflicts. The terroristic attack of 11 September or the attacks of ISIS on Syria and Iraq are the attack of "foreign bodies" to infiltrate political bodies of states to attain an autoimmunity process for themselves (280-1). Derrida's analysis of the metaphor of autoimmunity is systematic and political, rather than a moral perspective.

Both terrorism and counterterrorism operate relationaly, and reduce to an ideological slogan with an absolute evil (287). However, discussing about their rightfulness is difficult because their actions, discourse, and their targets are opened onto an undetermined future. Indeed, they do not have horizons of possibility that can be foreseen. As Caze indicates, Derrida characterizes the autoimmunity as "the strange behavior [that] a living being in quasi-suicidal fashion destroys its own protection to immunize itself against its own immunity" (605). Hence, the complexity of autoimmunity demands a further level of meaning by more explaining the concept of immunity against immunity which terrorists protect itself against their self-protection by destroying its own immune system (606). Overall, the autoimmunity is the reflection of us to the events of outside, caused our protection to be breached, whereas the immunity is the absolute protection from the Others. Therefore, the autoimmunity can be strong if we keep our commitments and our response to terrorism but without further violence and evil.

The response to terrorism should follow a model to protect humanistic values. From time to time, the concept of violence and evil is changed and depends on their label by various states. For instance, George W. Bush labeled Iran, Iraq, and North Korea an 'axis of evil' or Ronald Reagan labeled the Soviet Union an 'evil empire' in 1983 (Card, Confronting Evils 3). The scope of evil should be narrow and distinguished from lesser wrongs, so we should have the attention to its harm and its agents (5). According to Card, none of persons should be labelled as evil even Saddam Hussein or George W. Bush, but we should focus on deeds and institutions of evil (Ibid). However, it seems that Card's argument is not justifiable because humans are distinguished from animals due to their aptitudes and their potentials. Animals fight and kill weaker animals to survive themselves. However, humans possess consciousness, perception, and impression, so they cannot think only of their own survival. Here, the relationship between politics and the epistemology of humans is necessary to distinguish humans' stand and their dignity from the domain of their animality.

Certainly, politicians establish political institutions and organizations. All infrastructures of politics are based on individuals' thoughts which make a collective wisdom. Hence, we should transform the political deeds from organized states to individuals who work there and execute the law because the states have been shaped by a collective wisdom. As a result, both Saddam Hussein and George W. Bush, unlike Card's view, are the main perpetrators who make the structure of politics by their own ideas to protect their positions.

Terrorists have an intention to make a heavy loss of civilians' life indiscriminately to produce massive chaos with long term impact (Card, Questions Regarding a War on Terrorism 136). Terrorists' target is not to create peace, and their leaders are not identified, such as the unknown leader of al- Qaeda or ISIS. Although counterterrorism is necessary to make a stable society, it is morally problematic in performing behaviors and rules, putting together a legitimate military, and producing an international atmosphere of fear and uncertainty for terrorists.(138). There is different between the war on terrorism and the war on drugs or on crimes. The last two aims 
to create a peace with criminal organizations to prevent from harmful activities for humans, but there is no moral or political profit for them. Card claims that terrorism is not morally inexcusable, so international criminal courts can judge about terrorists whether they are excusable or inexcusable. In addition, nations should take responsibility together for preserving the law and should support an international criminal court (148).

Particularly, different models of terrorism which highlight different elements including "the [coercive] model with stressing the projects of terrorists, their thinking, and what they achieve; [also,] 'the group target model,' which is means to terrorists' end, focuses on the perception of victims to demoralizing them" (152). In the coercive model, terrorists' pressure on governments is increased to attain a direct target, such as releasing prisoners or altering policies. For example, "the 1970 bombing by students who demanded of the US to get out of Vietnam or at least to stop using napalm..., kidnap for ransom, or some forms of extortion (153).

It is necessary to mention that the actions of terrorist cause chaos in the life of people although their primary motivation is to free humans from colonialists and exploiters. As a matter of fact, the real terrorism is not identified by the ostensible actions, but to gain a greater insight about terrorism, "we need to recognize many cases of publicly invisible terrorism seriously as high-profile cases involving governments and other public policy-makers" (Card, Recognizing Terrorism 1). Consequently, the fundamental reasons of terrorism should be sought in the mutation of identity of those who are interested in changing the politics of a society by the extreme violence, led to abolish innocent civilians and to destabilize the organized states.

\section{CONCLUSION AND IMPLICATIONS}

The purpose of the current research was to rethink politics in a situation of statelessness which is parallel with rethinking the philosophy of terror as a phenomenon. The phenomenology of terrorism was investigated to identify different approaches about the relationship between human beings to unfold the infrastructure of connection between the $I$ and the Other. The present paper examined the various arguments about using relationally the formula of 'ends justify means' rather than absolutely. Moreover, conceptualizing violence and counterviolence revealed the domain of permissible of counterviolence to achieve the categories of personal identity, self-respect, decolonization, as well as protecting culture and territories. In the end, the mainspring of terrorism is demonstrated to defend personal identity and to develop self-respect as primary targets, but the targets are gradually changed to annihilate civilians and to occupy other territories, as well as terrorists are altered to new leaders who oppress their nations because of abusing their power.

The main core of this paper is centralized on the formula of Trotsky who asserts 'ends justify means.' The justification of this claim requires several presuppositions to confront practically with terrorism, which has increased in the technological world. On the one hand, As Trotsky mentions, using the means should be conditioned since we do not know about the essence of ends which is not yet attained (Birchall 254). Hence, we must differentiate between terrorists' actions that unconditionally use means and conditional violent actions to achieve the determined targets.

On the other hand, the two parts of Fanon's declaration based on promoting individual self-respect and realizing political independence are justifiable. However, the target of creating a new humanity is disapproval because it directs towards absolutism, that is, using absolute means to achieve the end. Obviously, we require to reform states by ruling the law accurately or even changing the law to rehabilitate the personal identity of nations. It is impossible to deconstruct humans' personal identity by revolutionary actions and construct a new personal identity or a new human, but they can only return their own identity, self-respect, and protect their culture through protesting, the stoppage of work, boycotting buses, and so on. Violence should be limited to eliminate decayed thoughts of colonialists and exploiters whose targets is to expand their control on other territories for using natural sources and to change nations' cultures.

It may be some hesitations about the conditional ways to confront with the category of terrorism since it is claimed that we cannot eliminate colonialists and exploiters without murdering. The primary aim of terrorists is to annihilate colonialists physically to wipe their thoughts, but its outcome is to assassinate innocent civilians, such as the violent attack of the U.S.A to Afghanistan is due to the bin Ladinian's violent attack in 11 September 2001. Frequently, the decayed thoughts of depredators will be removed by substituting new thoughts which profit all humans, but not with murdering depredators who their thoughts are systematically localized in states. To clarify, the politics of the U.S.A does not depend on its president because its politics' system has been stabilized for long years, so if terrorists assassinate the president to defend their territories in Afghanistan or Iraq, they cannot afford to eliminate the colonialist thought, but rather their actions cause the political system of the United States to be much more enforced.

Comparatively, the role of religion is to compensate the lack of political coherence and the moral certainty to convince those who intend to combat against colonialists. However, religious people should not interpret the religious texts or quotes based on their own intentions. Religions generally stress on ethical aspects of deeds, so they never advise to begin the assassination of the Other, unless the Other intends to endanger the I's life, so the $I$ should only defend himself. However, terrorists, either Christians, Muslims, or Jewish, consider the assassination of the Others as a primary means to achieve their primary ends, such as restoring their personal identity and decolonizing. To acquire these ends, the relational violence, rather than absolute violence, manifests itself in counterviolence without any extreme violence. Equally Important, the failure of absolutism is due to become unified of the $I$ and the Other as Levinas indicates. He claims that the interlocutor between the $I$ and the Other and hearing the voice of the Other is a barrier for terrorizing because the $I$ possesses the being of the Other (Keen 449). The sameness of the $I$ and the Other as nations and settlers is permissible, but the sameness of 
colonialists or exploitative states and nations is not justifiable. Nations and settlers should live in peaceful coexistence with each other to combat with terrorism, so they do not have dichotomous identities because of their similar target. However, nations and colonialists like the $I$ and the Other cannot have the same identity because of their different targets.

Although colonialists' or oppressing states' aims is to attain their own profits and developing territories by abusing from the resources of countries, the revenge of them by terrorizing and murdering would not be ethical. If the revenge increases, the spiral of violence and counterviolence between oppressing states and nations is constantly escalated, as the case was in Holocaust in which Zionists invade Palestinians because they became avenger. Therefore, the reasonable approach to tackle this issue can be through the discourse between these groups by different methods, such as protesting or making a real international court without any directorial and commanding aspects on behalf of colonialists. Ultimately, counterviolence should be restricted to defend of the personal identity and territories by guerillas against colonialists or through libertarian movements against oppressing states.

\section{REFERENCES}

Arendt, Hannah. The Human Condition. Chicago: Chicago U, 1958. Print.

Arendt, Hannah. On Violence. New York: Harcourt, Brace \& world, Inc, 1970. Print

Arendt, Hannah. The Origin of Totalitarian. Harcourt: California, 1985. Print

Bambach, Charles. "Heidegger, Technology, and the Homeland." The Germanic Review: Literature, Culture, Theory. 78.4 (2003): 267-282. Web. 6 November 2017.

Barrelle, Kate. "Pro-Integration: Disengagement from and Life After Extremism." Behavioral Sciences of Terrorism and Political aggression. 7.2 (2015): 129-149. Web. 21 November 2017.

Bender, David L. \& Bruno Leone. Eds. Terrorism: Opposing Viewpoints. Minnesota: Greenhaven press, 1986. Print.

Birchall, Ian. "Sartre and Terror." Sartre Studies International. 11.1 (2005): 251-264. Web. 8 November 2017.

Caze, Marguerite La. "Terrorism and Trauma: Negotiating Derridean 'Autoimmunity'." Philosophy and Social Criticism. 37.5 (2011): 605-619.Web. 28 November 2017.

Card, Claudia. "Questions Regarding a War on Terrorism." Hypatia, Feminist Philosophy and the Problem of Evil. 18.1 (2003): 164-169. Web. 29 November 2017.

Card, Claudia. "Recognizing Terrorism." The Journal of Ethics. 11.1 (2007): 1-29. Web. 29 November 2017.

Card, Claudia. Confronting Evils: Terrorism, Torture, Genocide. New York: Cambridge, 2010. Print.

Crooks, Kalpana Seshadri. "I am a Master': Terrorism, Masculinity, and Political Violence in Frantz Fanon." Paralax. 8.2 (2002): 84-98. Web. 20 December 2017.

Curtis, Neal. "Tragedy and politics." Philosophy and Social Criticism. 33.7 (2007): 860-879. Web. 7 November 2017.

Derrida, Jacques. Adieu to Emmanuel Levinas. Trans. PascaleAnne Braute \& Michael Naas. Standford: Standford U, 1999.Print.

Derrida, Jacques, Ferraris, Maurizio \& Donis, Giacomo. A Taste for the Secret, Cambridge: Polity, 2001. Print.

Detmer, David. "Sartre on Freedom and Education." Studies International. 11.1 (2005): 78-90. Web. 7 November 2017.

Dodd, James. Violence and Phenomenology. New York: Routledge, 2009. Print.

Fanon, Frantz. The Wretched of the Earth. New York: Grove, 1965. Print.

Fanon, Frantz. Black Skin White Mask. New York: Grove, 1967. Print.
Ferrarello, Susi. Husserl's Ethics and practical Intentionality. London, Bloomsbury, 2016. Print.

Fleming, Michael. "Sartre on Violence: Not So Ambivalent." Sartre Studies International. 17.1 (2011): 20-40. Web. 9 November 2017.

Fry, Karin. "Hannah Arendt and the War in Iraq." Philosophical Topics. 39.2 (2011): 41-51. Web. 16 November 2017. Heidegger, Martin. Being and Time. Trans, Joan Stambaugh. New York: State U, 2010. Print.

Husserl Edmund. Ideas. Trans. W. R. Boyce Gibson. London: George Allen and Unwin Ltd, 1952. Print.

Härter, Karl. "Political crime in early modern Europe: Assassination, legal responses and popular print media." European Journal of Criminology.11.2 (2014): 142-168. Web. 20 November 2017.

Hodge, Joanna. "Philosophy in a Time of Terror: Kant and Derrida." Women: a Cultural Review. 22.2/3 (2011): 204-219. Web. 3 November 2017.

Keen, Gabriel and Deron, Boyles. "Sense, Nonsense, and Violence: Levinas and Internal Logic of School Shootings." Educational Theory. 65 (2015): 442-458. Web. 23 November 2017.

Kurian, George Thomas \& James E. alt, et al. The Encyclopedia of Political science. 1 vols. Washington. D.C.: CQ, 2011. Print.

Levinas, Emmanuel. Totality and Infinity: An Essay on exteriority. Trans. Alphonso Lingis. Pittsburgh, Pennsylvania: Duquesne U, 1969. Print.

Levinas, Emmanuel. Collected Philosophical Papers. Trans. Alphano Lingis. Lancaster: Martinus Nijhoff, 1987. Print.

Merleau-Ponty, Maurice. Institution and Passivity: Course Notes from the Collège de France (1954-1955). Eds, James M. Edie, Snthony J. Steinbock and John McCumber. Evanston: Northwestern U, 2010. Print.

Merleau-Ponty, Maurice. Humanism and Terror: An Essay on the Communist Problem. Trans. John O'Neill. Boston: Bacon, 1969. Print.

Mitchell, Andrew J. "Heidegger and Terrorism." Research in Philosophy. 35 (2005): 181-218. Web. 11 Nov 2017.

Mokhtan, Sa'at. "The woman interviewed the ISIL commander." Tasnim. Khabarian, 17 December 2017. 18 December 2017.

Morris, Travis \& John P. Crank. "Toward a Phenomenology of Terrorism: implications for Research and Policy." Crime Law Soc Change. 56 (2011): 219-242. Web, 1November 2017.

Pisoiu, Daniela. Arguing Counter Terrorism: New Perspectives." Ed. Richard Jackson. University of Otago: New Zealand, 2014 Routledge critical terrorism studies. Web. 20 November 2017.

Pugliese, Joseph. "Necro-ethics of Terrorism." Law Critique. 21 (2010): 213-231. Web. 21 November 2017.

Rockmore, Tom \& Joseph Margolis, Eds. The Heidegger Case: On Philosophy and Politics. Philadelphia: Temple U, 1992. Print.

Santoni, Ronald E. Sartre on Violence: Curiously Ambivalent. Pennsylvania: The Pennsylvania State U, 2003. Print.

Scrivner, Eric. "Technological Criticism: Heidegger and Enframing." On Philosophy. 20 Feb 2014. Web. 6 November 2017.

Sharma, Anuradha. "Violence and Phenomenology." ProcediaSocial and Behavioral Sciences. 92 (2013): 868-873. Web. 1 November 2017.

Smith, David Woodruff \& Ronald McIntyer. Husserl and Intentionality: A Study of Mind, Meaning, and Language. Dordrecht: D. Reidel, 1994. Print

Sonnleitner, Michael W. "Of Logic and Liberation: Frantz Fanon on Terrorism." Black Studies. 17.3 (1987): 287-304. Web. 18 November 2017.

Staudigl, Michael. "Towards a Relational Phenomenology of Violence." Human Stidoes. 36.1 (2013): 43-66. Web. 1 November 2017.

Tahmasebi, Birginia, Victoria. Emmanuel Levinas and the Politics of Non-Violence. Toronto: T U, 2014. Print.

Thomas, Elisabeth Louise. Emmanuel Levinas, Ethics, Justice, and the Human beyond Being. Trans. Ed. Robert Bernasconi. New York: Routledge, 2004. Print.

West, Alzo David. "Derrida, Terrorism, And Communism: A Comment On 'Autoimmunity:' Real and Symbolic Suicides.' Cosmos and History: The Journal of Natural and Social Philosophy. 5.2 (2009): 226-235. Web. 26 December 2017. 